\title{
RAINFALL CHARACTERIZATION AND SEDIMENTOLOGICAL RESPONSES OF WATERSHEDS WITH DIFFERENT LAND USES TO PRECIPITATION IN THE SEMIARID REGION OF BRAZIL
}

\author{
JACQUES CARVALHO RIBEIRO FILHO ${ }^{2 *}$, HELBA ARAÚJO DE QUEIROZ PALÁCIO ${ }^{3}$, EUNICE MAIA DE \\ ANDRADE ${ }^{4}$, JÚLIO CÉSAR NEVES DOS SANTOS ${ }^{5}$, JOSÉ BANDEIRA BRASIL ${ }^{4}$
}

\begin{abstract}
The objective of this work was to evaluated the precipitation characteristics (depth, I30 and erosivity) and their effects on sediment production in three watersheds under different managements of land use 35-year regenerating Caatinga (RC), thinned Caatinga (TC), which underwent thinning of trees with diameter smaller than $10 \mathrm{~cm}$; and deforested Caatinga (followed by burning and pasture) (DC). The experimente was conducted in the central, tropical semiarid region of the State of Ceará, Brazil. The precipitation events, surface runoff and sediment production were monitored from 2010 to 2015 . The precipitation characteristics were subjected to Pearson's correlation at 1 and $5 \%$ of significance and the events that produced sediments in each watershed were hierarchically grouped by hierarchical cluster analysis technique. Two hundred precipitation events were recorded, with 23 (RC), 18 (TC) and 43 (DC) events producing sediments. The use of thinning (TC) decreased the sediment production by $53.5 \%$, while the deforestation, burn and pasture cultivation (DC) increased soil losses by $14 \%$, compared with the RC. The sediment production was greatly correlated with the I30 in the three watersheds, denoting the erosion process great dependence on the precipitation intensity.
\end{abstract}

Keywords: Precipitation. Sediment Production. Watersheds.

\section{CARACTERISTICAS DAS CHUVAS E RESPOSTAS SEDIMENTOLOGICAS EM DIFERENTES USOS DO SOLO NO SEMIÁRIDO}

\begin{abstract}
RESUMO - Obejtivou-se com este estudo investigar as caracteristicas das chuvas (altura precipitada, I30 e erosividade) e suas correlações com a produção de sedimentos em três microbacias submetidas aos seguintes manejos: Caatinga em Regeneração (CER) há 35 anos; Caatinga Raleada (CRA) passou pelo raleio das árvores com diâmetro menor que $10 \mathrm{~cm}$; Desmatamento/Queima/Plantio de Pastagem (DQP). A área de estudo é representative de região semiárida tropical e está localizada na parte central do estado do Ceará. Foram monitorados eventos puviométricos, escoamento superficial e produção de sedimentosdos anos de 2010 a 2015. As características das chuvas foram submetidas a correlação de Pearson a nível de 1 e $5 \%$ de significância e os eventos que produziram sedimentos em cada microbacia foram agrupados hierarquicamente pela técnica de Análise de Agrupamento Hierárquico. Ao todo foram registrados 200 eventos pluviométricos dos quais $23,18 \mathrm{e}$ 43 eventos produziram sedimentos nas microbacias CER, CRA e DQP respectivamente. A adoção do manejos de raleamento reduziu a produção de sedimentos em 53,5 \%, enquanto que o DQP promoveu um aumento das perdas de solo em $14 \%$ em relação à CER. A produção de sedimentos expressou uma maior correlação com o I30 para as três microbacias expressando a maior dependência do processo erosive da intensidade das chuvas.
\end{abstract}

Palavras-chave: Precipitação pluviométrica. Produção de sedimentos. Micorbacias.

\footnotetext{
*Corresponding author

${ }^{1}$ Received for publication in $05 / 27 / 2016$; accepted in $10 / 18 / 2016$.

Paper extracted from the graduation monograph of the first author.

${ }^{2}$ Departament of Environmental and Technological Sciences, Universidade Federal Rural do Semi-Árido, Mossoró, RN, Brazil; jacquesfilho1@hotmail.com.

${ }^{3}$ Departament of Education, Instituto Federal do Ceará, Iguatu, CE, Brazil; helbaraujo23@yahoo.com.br.

${ }^{4}$ Agricultural Engineering Departament, Universidade Federal do Ceará, Fortaleza, CE, Brazil; eandrade@ufc.br, josebbrasil@gmail.com.

${ }_{5}^{5}$ Departament of Education, Instituto Federal do Triângulo Mineiro - Campus Uberlândia, Uberlândia, MG, Brazil; juliocesarnds@yahoo.com.br.
} 


\section{INTRODUCTION}

Soil loss is dangerous to the environment of terrestrial ecosystems when exceeds the tolerable level and may be intensified by human disturbances (LIU et al., 2012). The intensification of human activities on natural resources, especially in semiarid regions, affect the soil physical properties and hydrological and sedimentological processes of watersheds, such as water retention, runoff and sediment production (CHAMIZO et al. 2012).

Local and regional-scale studies have been conducted to evaluate and understand environmental sustainability mechanisms (SUN; NI; BORTHWICK, 2010; FANG et al. 2013). However, few studies assessed the effects of changes in land use in the Brazilian semiarid on hydrological and sedimentological processes, which cause irreparable damages, such as siltation and eutrophication of water bodies. The obtaining of a better correlation between erosivity and soil losses is limited by the high variability and low information on precipitation physical characteristics (ALBUQUERQUE et al., 2005; LIMA et al., 2013; WESTER; WASKLEWICZ; STALEY, 2014).

The main process generating runoff in the Brazilian semiarid region is the Hortonian (precipitation intensity exceeding the infiltration capacity). The water flow on long surfaces increases the probability of infiltration and sediment deposition due to absence of transport (FANG et al., 2012). Moreover, the extrapolation of estimates between scales is limited by the heterogeneity of watersheds, usually not represented at small scale (BOIX-FAYOS et al., 2006).

The soils of arid and semiarid regions, with few exceptions, are undeveloped, rocky and shallow, with low water retention capacity, limiting primary productions (CHAMIZO et al., 2012). These soils have, in general, low organic matter content and high silt proportion, which reduce the aggregate stability and consequently, are more susceptible to erosion, comparing with soil of different characteristics. Therefore, the rapid erosion of agricultural areas has significantly contributing to desertification of many areas of the Brazilian semiarid region (ONDA; DIETRICH; BOOKER, 2008). These problems are even more noticeable in lands that have steep slopes and altered or absent vegetation cover (OLIVEIRA et al., 2010; RODRIGUES et al., 2013).

The information on the precipitation characteristics and vegetation distribution in a semiarid environment are the basis to prevent of soil loss (ZHOU et al., 2016). Vegetation management can significantly decrease water infiltration rates and increase surface runoff and erosion (SANTOS, 2012). Moreover, soil management practices may modify the soil structural and hydrologic conditions, reducing the total biomass covering it and changing the dominant plant species (CAMPO et al., 2006). In this context, the objective of this work was to evaluated precipitation characteristics and their effects on sediment production in three watersheds under different land managements, in the Brazilian semiarid region.

\section{MATERIAL AND METHODS}

The watersheds evaluated are from the Iguatu Experimental Basin (IEB), located in the Alto Jaguaribe basin, Iguatu, Mid-South region of the State of Ceara, Brazil (Figure 1), in a Federal area controlled by the Federal Institute of Education, Science and Technology of Ceará, Iguatu campus.
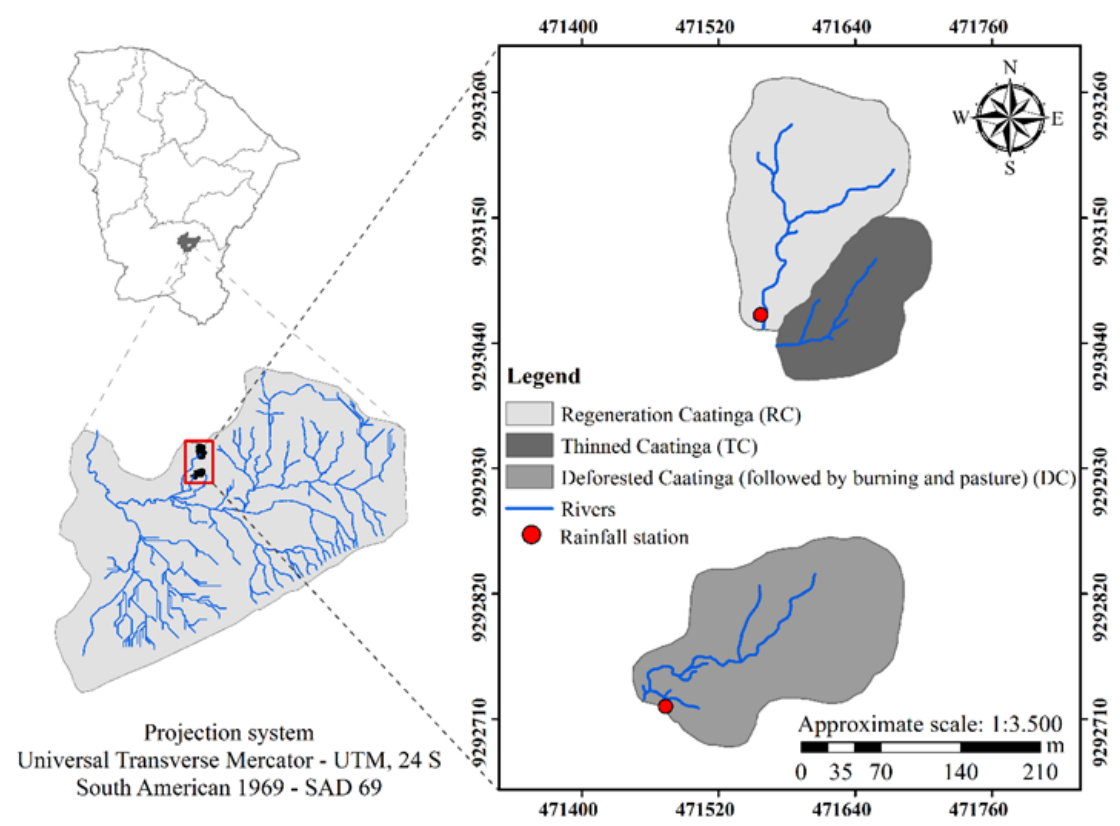

Figure 1. Location of the experimental watersheds.

Rev. Caatinga, Mossoró, v. 30, n. 2, p. 468 - 478, abr. - jun., 2017 
The region climate is type $B \mathrm{BW}^{\prime} \mathrm{h}$ ' (hot semiarid with average temperature over $18^{\circ} \mathrm{C}$ in the coldest month), with aridity index of 0.44 , i.e., semiarid. The region average potential evaporation is $1,988 \mathrm{~mm} \mathrm{yr}^{-1}$. The average precipitation (1932-2013) in Iguatu is $864 \pm 304 \mathrm{~mm}$. The annual distribution of rainfall in the region is concentrated (85\%) from January to May, with about $30 \%$ in March (SANTOS, 2012).
The soils of the experimental area were classified as typical carbonate ebanic Vertisol (EMBRAPA, 2013), with depths of up to $137 \mathrm{~cm}$ (Table 1), great contents of silt in subsurface layers (ARAÚJO NETO, 2012), and little rugged terrain. The drainage of the watersheds is formed by first and second order streams, according to the Strahler classification, thus, they are spring areas. The watersheds evaluated showed different morphometric classification (Table 1).

Table 1. Mopphometric classification of the watersheds evalutated.

\begin{tabular}{|c|c|c|c|c|}
\hline \multirow{2}{*}{ Characteristics } & \multicolumn{3}{|c|}{ Watersheds } & \multirow[b]{2}{*}{ Unit } \\
\hline & RC & TC & DC & \\
\hline Area & 2.06 & 1.15 & 1.19 & ha \\
\hline Perimeter & 594.50 & 478.35 & 491.75 & $\mathrm{~m}$ \\
\hline Talvegue length (Lt) & 183.87 & 120.54 & 142.80 & $\mathrm{~m}$ \\
\hline Length of the main stream (Lcp) & 252.11 & 147.18 & 150.30 & $\mathrm{~m}$ \\
\hline Watershed length (Lb) & 204.40 & 18.17 & 208.50 & $\mathrm{~m}$ \\
\hline Watershed average slope (Db) & 10.59 & 8.72 & 10.63 & $\%$ \\
\hline Form factor (Rf) & 0.49 & 0.32 & 0.27 & - \\
\hline Coefficient of compactness (Kc) & 1.16 & 1.25 & 1.26 & - \\
\hline Time of concentration $(\mathrm{Tc})$ & 33.80 & 20.00 & 30.00 & $\min$ \\
\hline Sinuosity of the main stream (Sin) & 1.40 & 1.20 & 1.05 & - \\
\hline
\end{tabular}

$\mathrm{RC}$ - regeneration Caatinga; TC - thinned Caatinga; DC - Deforested Caatinga (followed by burning and pasture). (Adapted from SANTOS, 2012).

The experiment was conducted from 2010 to 2015, except 2014, when the monitoring of the events generating runoff was disabled due to technical and operational problems. Three managements of soil use were evaluated, represented by a regenerating Caatinga area (RC) (Figure 2a), densely covered with Caatinga plants, with original vegetation regenerating over 35 years; a thinned Caatinga area (TC) (Figure 2b), which underwent thinning of trees with diameter at breast height smaller than $10 \mathrm{~cm}$ in January 2009, improving the development of herbaceous plants by allowing more sunlight penetration, according to the methodology adapted by Araújo Filho (1992); and a deforested Caatinga (followed by burning and pasture) (DC), with burning carried out in November 2009 and planting of grass (Andropogon gayanus Kunt) in January 15, 2010 (Figure 2c).
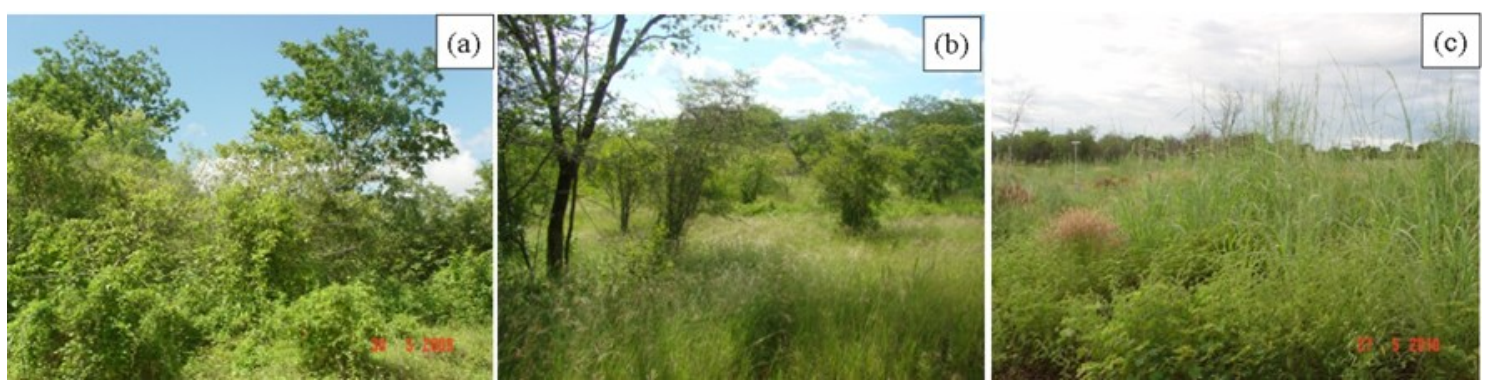

Figure 2. Experimental watersheds of the Iguatu Experimental Basin, with regenerating Caatinga (a), thinned Caatinga (b) and deforested Caatinga (followed by burning and pasture) (c).

Precipitation data were obtained from an automated weather station installed in the experimental area, which contained a rocker rain gauge with data acquisition every five minutes.

The surface runoff was monitored with

Parshall flumes installed on the watersheds estuary, 
equipped with sensors (Figure 3a) to measure the water level of the flow, with data acquisition every five minutes.
The sediment production upstream of the flume was monitored with 180 -liter pits collecting dragged sediment by the river course and a tower for collect suspended sediments (Figures $3 b$ and c).
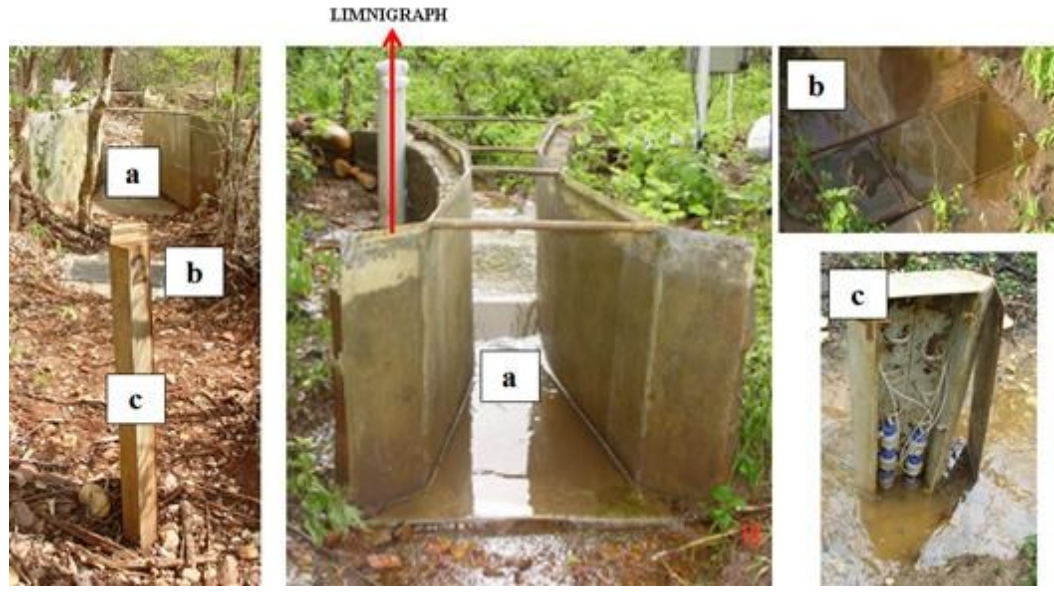

Figure 3. Parshall flume (a), pit to collect dragged sediment (b) and tower to collect suspended sediment (c) installed in each watershade of the Iguatu Experimental Basin.

The data of precipitation, runoff and suspended and dragged sediments were collected every 24 hours, according to methodology described by Dereczynski, Oliveira and Machado (2009). The retained material (dragged sediments) in the pit was homogenized and, subsequently, a $500-\mathrm{mL}$ sample was collected to determine the total solids. The pit was emptied after each collection and thus prepared for sampling of the new runoff events.

The automatic sediment collecting tower had six 100-mL bottles spaced $15 \mathrm{~cm}$ apart (Figure $3 \mathrm{c}$ ). The water samples were collected soon after the surface runoff events that reached the collection point in the sediment tower and taken to the laboratory. The total solid concentration analysis was carried out following the methodology described by Piveli and Kato (2005), considering the events with suspended and dragged soil.

The precipitation data were used to calculate the intensities (I) of each event $\left(\mathrm{mm} \mathrm{h}^{-1}\right)$ and the maximum precipitation intensity over thirty minutes $\left(\mathrm{I} 30, \mathrm{~mm} \mathrm{~h}^{-1}\right)$. The kinetic energy (KE) associated with rainfall $\left(\mathrm{MJ} \mathrm{ha}^{-1} \mathrm{~mm}^{-1}\right)$ was determinate by the Equation 1, proposed by Wischmeier and Smith (1958) and modified by Foster et al. (1981),

$$
\mathrm{KE}=0.119+0.0877 \log \mathrm{I}
$$

in which $\mathrm{KE}$ is the rainfall kinetic energy (MJ ha $\mathrm{hm}^{-1}$ ) and $\mathrm{I}$ is the rainfall intensity $\left(\mathrm{mm} \mathrm{h}^{-1}\right)$.

The values obtained from the Equation 1 were used to calculate the erosivity index (EI30) (SANTOS et al., 2014) using the Equation 2,

$$
\mathrm{EI} 30=\mathrm{KE} \text { I30máx } \mathrm{P}
$$

in which EI30 is the erosivity index (MJ mm ha ${ }^{-1} \mathrm{~h}^{-1}$ ), I30máx is the average maximum intensity of precipitation in thirty minutes $\left(\mathrm{mm} \mathrm{h}^{-1}\right)$ and $\mathrm{P}$ is the precipitation depth ( $\mathrm{mm})$.

The software SPSS-16.0 (Statistical Package for the Social Sciences) was used for statistical analysis. The variables precipitation depth, I30, erosivity and sediment production were subjected to Pearson's correlation, which measures the linear correlation level between two variables and their significance at 1 and $5 \%$. The Lilliefors test was used to verify the normality of the data set.

The rainfalls were divided into groups through multivariate analysis (hierarchical cluster analysis), considering their depth, I30, erosivity and sediment productions, to assess the similarity between precipitation events and their effects in sediment production in each watershed.

The actual variables used for this study were classificatory variables, thus, the z-score standardization was used, adopting the Euclidean Square Distance and the algorithm of the Ward link method as measures of similarity.

\section{RESULTS AND DISCUSSION}

The precipitation during the study period (2010, 2011, 2012, 2013 and 2015) was above the historical average for the region only in 2011, which had a total annual precipitation of $1416.8 \mathrm{~mm}$ (Table 2 ). Two hundred rainfall events occurred during the study period. The watershed with regenerating Caatinga (RC) had surface runoff (SR) in 40 events, 
and sediment (dragged and suspended fractions) production (SP) in only 23 events. The watershed with thinned Caatinga (TC) had SR in 25 and SP in 18 events. The watershed with deforested Caatinga (followed by burning and pasture) (DC) had the highest number of events with SR (65), with 43 with SP. According to Wester, Wasklewicz and Staley (2014), soil exposure is one of the main factors for sediment transport in areas with burned vegetation.

Table 2. Hydro-sedimentological synthesis of the study period (2010 to 2015) in the watersheds with different vegetation covers of the Iguatu Experimental Basin.

\begin{tabular}{rcrrrrrrrrr}
\hline \multirow{2}{*}{$\begin{array}{c}\text { PPT } \\
(\mathrm{mm})\end{array}$} & $\begin{array}{c}\text { Number of } \\
\text { events with } \\
\text { PPT }\end{array}$ & $\begin{array}{c}\text { Number of } \\
\text { events with } \\
\text { SR }\end{array}$ & $\begin{array}{c}\text { Number of } \\
\text { events with } \\
\text { SP }\end{array}$ & $\begin{array}{c}\text { SP } \\
\left(\mathrm{kg} \mathrm{ha}^{1}\right)\end{array}$ & $\begin{array}{c}\text { Number of } \\
\text { events with } \\
\text { SR }\end{array}$ & $\begin{array}{c}\text { Number } \\
\text { of events } \\
\text { with SP }\end{array}$ & $\begin{array}{c}\text { SP } \\
\left(\mathrm{kg} \mathrm{ha}^{1}\right)\end{array}$ & $\begin{array}{c}\text { Number } \\
\text { of events } \\
\text { with SR }\end{array}$ & $\begin{array}{c}\text { Number of } \\
\text { events with } \\
\text { SP }\end{array}$ & $\begin{array}{c}\text { SP } \\
\left(\mathrm{kg} \mathrm{ha}^{1}\right)\end{array}$ \\
\hline 717.4 & 45 & 7 & 2 & 186.7 & 5 & 1 & 15.4 & 9 & 7 & 2921.0 \\
1416.8 & 58 & 19 & 12 & 3372.2 & 13 & 12 & 2193.6 & 35 & 23 & 2032.5 \\
807.5 & 34 & 10 & 5 & 1175.9 & 4 & 1 & 0.3 & 16 & 8 & 501.7 \\
755.0 & 34 & 2 & 2 & 149.5 & 2 & 2 & 55.7 & 2 & 2 & 197.0 \\
518.4 & 29 & 2 & 2 & 7.2 & 1 & 1 & 2.8 & 3 & 3 & 39.9 \\
\hline 4215.1 & 200 & 40 & 23 & 4873.5 & 25 & 18 & 2267.7 & 65 & 43 & 5692.1 \\
\hline
\end{tabular}

PPT - Precipitation; SR - surface runoff; SP - sediment production; RC - regenerating Caatinga; TC - thinned Caatinga; $\mathrm{DC}$ - and deforested Caatinga (followed by burning and pasture).

The watershed DC had 20 and 25 more events with SP than the RC and TC, respectively. Considering the physiographic similarity between the studied watersheds (Table 1), the amounts of events with SP in watersheds DC and TC denote the effect of weed control in sedimentological responses. The deforestation and total vegetation burning in the DC management (Figure 2c) left the soil completely exposed in the first year of study until the establishment of the grass after the start of the rainy season.

The thinning of trees with diameter smaller than $10 \mathrm{~cm}$ of the TC management allowed more sunlight penetration through the canopy of trees, with subsequent germination of the herbaceous seed bank in the lower soil cover (Figure 2b).

The herbaceous vegetation had the best development in the watershed TC, compared with the native vegetation, promoting a reduction of surface runoff. Thus, the development of the herbaceous vegetation, which covered almost the entire soil surface of the watershed TC, attenuated the direct impact of rain drops and promoted greater resistance to surface runoff (THOMAZ, 2009), reducing its magnitude and providing greater water infiltration into the soil.

The precipitation in 2010 was below the historical average, however, this precipitation generated the greatest SP $\left(2,921 \mathrm{~kg} \mathrm{ha}^{-1}\right)$ in the watershed DC (Table 2). The greatest soil losses occurred in the first rainfall events, when the Andropogon gayanus Kunt grass was not yet established and the soil was exposed (SANTOS, 2012). Greater values of soil loss in the first year of use after burned have been found in other areas (CAMPO et al., 2006; ONDA; DIETRICH; BOOKER, 2008).

The SP of all soil use managements in 2011 (Table 2) were within the range set by FAO (1967) ( 2 to $4 \mathrm{Mg} \mathrm{ha}^{-1} \mathrm{yr}^{-1}$ ) to semiarid regions. This loss is related to the greater rainfall depth in this year (Table 2), which was $63.4 \%$ higher than the historical average. The lower SP in the watershed $\mathrm{DC}$ was related to the grass development (Figure 2c) which was already established and well-developed in 2011.

The characteristics precipitation depth, I30, SP and erosivity, and their correlations (Table 3) showed the I30 with significant correlation with SP in the three watersheds. The watershed TC presented the greatest correlation, showing that areas with dense herbaceous vegetation cover results in greater soil protection, requiring great rainfall intensities for disaggregation and sediment transport. Liu et al. (2012) evaluated three river basins in the Chinese semi-arid and found correlation between rainfall intensity and SP, with higher correlation in areas with dense vegetation. 
Table 3. Person's correlation between precipitstion (PPT), I30, sediment production, erosivity and accumulated preciipitstion in the experimental period, the three watersheds with different vegetation covers of the Iguatu Experimental Basin.

\begin{tabular}{|c|c|c|c|c|c|}
\hline $\mathrm{RC}$ & $\begin{array}{l}\text { PPT } \\
(\mathrm{mm})\end{array}$ & $\begin{array}{c}\mathrm{I} 30 \\
\left(\mathrm{~mm} \mathrm{~h}^{-1}\right)\end{array}$ & $\begin{array}{l}\text { Sediments production } \\
\qquad\left(\mathrm{kg} \mathrm{ha}^{-1}\right)\end{array}$ & $\begin{array}{c}\text { Erosivity (MJ mm } \\
\left.\text { ha }^{-1} h^{-1}\right)\end{array}$ & $\begin{array}{c}\text { Accumulated } \\
\text { PPT in last } 5 \\
\text { days }(\mathrm{mm})\end{array}$ \\
\hline $\mathrm{PPT}(\mathrm{mm})$ & 1 & & & & \\
\hline $\mathrm{I} 30\left(\mathrm{~mm} \mathrm{~h}^{-1}\right)$ & $0.676^{* *}$ & 1 & & & \\
\hline Sediments production $\left(\mathrm{kg} \mathrm{ha}^{-1}\right)$ & $0.290^{\mathrm{ns}}$ & $0.475^{*}$ & 1 & & \\
\hline Erosivivy $\left(\mathrm{MJ} \mathrm{mm} \mathrm{ha}{ }^{-1} \mathrm{~h}^{-1}\right)$ & $0.891^{* *}$ & $0.600 * *$ & $0.191^{\mathrm{ns}}$ & 1 & \\
\hline Accumulated PPT in last 5 days & $0.150^{\mathrm{ns}}$ & $0.021^{\mathrm{ns}}$ & $0.232^{\mathrm{ns}}$ & $0.135^{\mathrm{ns}}$ & 1 \\
\hline $\mathrm{TC}$ & $\begin{array}{l}\text { PPT } \\
(\mathrm{mm})\end{array}$ & $\begin{array}{c}\mathrm{I} 30 \\
\left(\mathrm{~mm} \mathrm{~h}^{-1}\right)\end{array}$ & $\begin{array}{l}\text { Sediments production } \\
\qquad\left(\mathrm{kg} \mathrm{ha}^{-1}\right)\end{array}$ & $\begin{array}{c}\text { Erosivity (MJ mm } \\
\left.\mathrm{ha}^{-1} \mathrm{~h}^{-1}\right)\end{array}$ & $\begin{array}{c}\text { Accumulated } \\
\text { PPT in last } 5 \\
\text { days }(\mathrm{mm})\end{array}$ \\
\hline PPT (mm) & 1 & & & & \\
\hline $\mathrm{I} 30\left(\mathrm{~mm} \mathrm{~h}^{-1}\right)$ & $0.757 * *$ & 1 & & & \\
\hline Sediments production $\left(\mathrm{kg} \mathrm{ha}^{-1}\right)$ & $0.255^{\mathrm{ns}}$ & $0.678^{* *}$ & 1 & & \\
\hline Erosivivy $\left(\mathrm{MJ} \mathrm{mm} \mathrm{ha}{ }^{-1} \mathrm{~h}^{-1}\right)$ & $0.953^{* *}$ & $0.720 * *$ & $0.307^{\mathrm{ns}}$ & 1 & \\
\hline Accumulated PPT in last 5 days & $0.180^{\text {ns }}$ & $0.233^{\text {ns }}$ & $0.235^{\text {ns }}$ & $0.265^{\text {ns }}$ & 1 \\
\hline $\mathrm{DC}$ & $\begin{array}{l}\mathrm{PPT} \\
(\mathrm{mm})\end{array}$ & $\begin{array}{c}\mathrm{I} 30 \\
\left(\mathrm{~mm} \mathrm{~h}^{-1}\right)\end{array}$ & $\begin{array}{l}\text { Sediments production } \\
\qquad\left(\mathrm{kg} \mathrm{ha}^{-1}\right)\end{array}$ & $\begin{array}{c}\text { Erosivity (MJ mm } \\
\left.\qquad \mathrm{ha}^{-1} \mathrm{~h}^{-1}\right)\end{array}$ & $\begin{array}{c}\text { Accumulated } \\
\text { PPT in last } 5 \\
\text { days }(\mathrm{mm})\end{array}$ \\
\hline PPT (mm) & 1 & & & & \\
\hline $\mathrm{I} 30\left(\mathrm{~mm} \mathrm{~h}^{-1}\right)$ & $0.713 * *$ & 1 & & & \\
\hline Sediments production $\left(\mathrm{kg} \mathrm{ha}^{-1}\right)$ & $0.350^{*}$ & $0.311 *$ & 1 & & \\
\hline Erosivivy $\left(\mathrm{MJ} \mathrm{mm} \mathrm{ha}{ }^{-1} \mathrm{~h}^{-1}\right)$ & $0.901 * *$ & $0.700 * *$ & $0.261^{\mathrm{ns}}$ & 1 & \\
\hline Accumulated PPT in last 5 days & $0.282^{\mathrm{ns}}$ & $0.108^{\mathrm{ns}}$ & $0.162^{\mathrm{ns}}$ & $0.285^{\mathrm{ns}}$ & 1 \\
\hline
\end{tabular}

${ }^{* *}$ Correlation significant at $1 \%, *$ correlation significant at $5 \%$, NS not significant correlation. Data subjected to the Lilliefors test for normality.

Cluster analysis were carried out to identify statistically similar events, in order to better understanding rainfall events that cause runoff. Three different groups of events were formed for the watershed RC. The formation of different groups express high temporal variability of events, which is a characteristic of the region (LIMA et al., 2013). The rainfall characteristics affected the grouping results of the watershed $\mathrm{RC}$, with the rainfall in group 1 presenting lower rainfall, I30 and erosivity, however, presenting the highest average of 5-day accumulated precipitation (Table 4). According to Santos et al. (2016), a 5-day accumulated precipitation is needed for low magnitude events (lower than $40 \mathrm{~mm}$ ) to generate runoff.

Table 4. Characteristis of the events grouped by hierarchical cluster analysis fpr the watershed with regenerating Caatinga pf the Iguatu Experimental Basin.

\begin{tabular}{clccc}
\hline & & & \\
& Variables & Regenerating Caatinga & & Group 3 \\
& Number of events & 8 & 12 & 3 \\
Precipitation & Average + SD & $38.17 \pm 19.40$ & $48.35 \pm 10.80$ & $109.23 \pm 46.10$ \\
$(\mathrm{~mm})$ & Median & 49.69 & 47.28 & 89.46 \\
& Maximum & 62.50 & 64.00 & 161.97 \\
& Minimum & 12.13 & 30.10 & 76.25 \\
\hline \multirow{2}{*}{ Accumulated } & Number of events & 8 & 12 & 3 \\
PPT in last & Average + SD & $109.18 \pm 16.70$ & $39.59 \pm 21.30$ & $16.20 \pm 24.00$ \\
& Median & 122.30 & 47.57 & 4.80 \\
& Maximum $(\mathrm{mm})$ & 145.38 & 68.38 & 43.80 \\
& Minimum & 8.00 & 0.00 & 0.00 \\
\hline
\end{tabular}


Table 4. Continuation.

\begin{tabular}{clccc}
\hline \multicolumn{5}{c}{ Regenerating Caatinga } \\
\hline & Variables & Group 1 & Group 2 & Group 3 \\
\hline & Number of events & 8 & 12 & 3 \\
& Average + SD & $40.13 \pm 20.10$ & $53.71 \pm 9.21$ & $84.37 \pm 13.10$ \\
$\mathrm{I} 30\left(\mathrm{~mm} \mathrm{~h}^{-1}\right)$ & Median & 48.10 & 54.92 & 84.37 \\
& Maximum & 67.84 & 66.14 & 97.50 \\
& Minimum & 12.72 & 36.46 & 71.23 \\
\hline \multirow{2}{*}{ Erosivity } & Number of events & 8 & 12 & 3 \\
$\left(\mathrm{MJ} \mathrm{mm} \mathrm{ha}{ }^{-1} \mathrm{~h}^{-1}\right)$ & Average + SD & $350.11 \pm 340.20$ & $472.39 \pm 280.40$ & $1831.07 \pm 1014.00$ \\
& Median & 264.62 & 465.65 & 1781.77 \\
& Maximum & 845.89 & 998.50 & 2868.87 \\
& Minimum & 8.00 & 3.55 & 842.57 \\
\hline
\end{tabular}

The group 2 of the watershed $\mathrm{RC}$ was differentiated by events with intermediate values for the four variables. Precipitation events with runoff were found in this group, even in events without 5 day accumulated precipitation, because of the intensity of rainfall exceeding the water infiltration capacity. The group 3 was differentiated by rainfall events of great depths, intensity and short duration, which explains the great erosivity and the low accumulated precipitation (Table 4). Liu et al. (2012) studied the rainfall as the source of sediment production in a semi-arid climate in the Yangjuangou basin (China), and found three rainfall groups according to the magnitudes of runoff coefficients, with greatest sediment production in group 3, which represented the greatest rainfall depths.

The results of the SP of each group (Figure 4) showed that most SP $\left(695.04 \mathrm{~kg} \mathrm{ha}^{-1}\right)$ occurred in one event of the group 1 , which recorded the greatest I30 (67.84 $\mathrm{mm} \mathrm{h}^{-1}$ ) (Table 4). The other events (groups 2 and 3) presented smaller SP (Figure 4), however, these SP was generated by their greatest rainfall depths, which had lower values of 5-day accumulated precipitation (Table 4). Studying the Spanish semiarid, Chamizo et al. (2012) found that rainfall of different intensities directly affect the SP and that the soil moisture is the determining factor for the runoff process (soil loss) in rainfall events of low depths and $\mathrm{I} 30$.

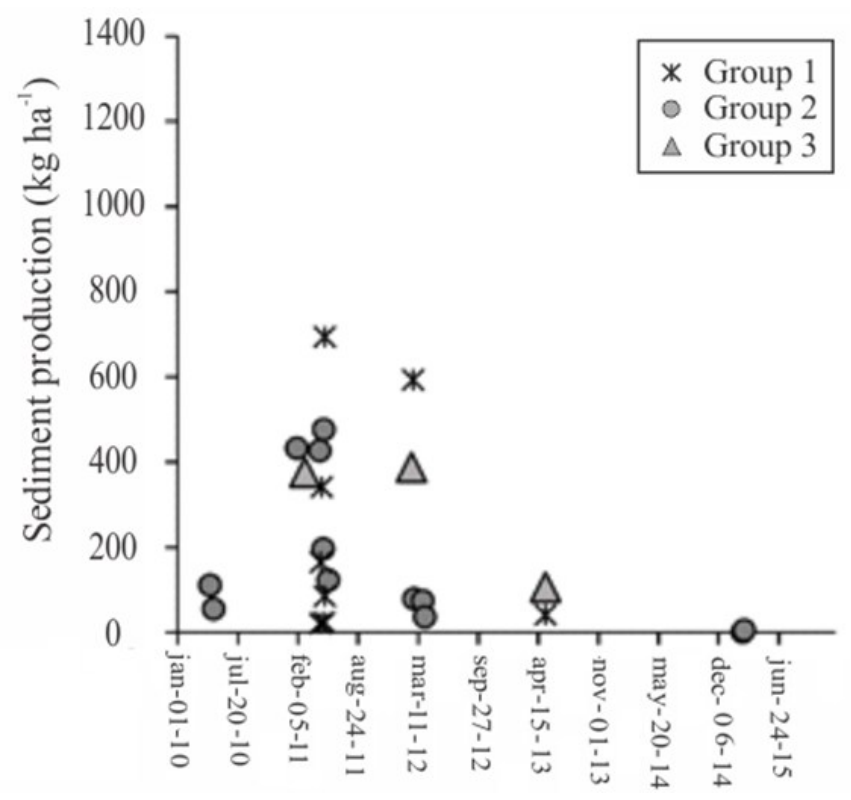

Figure 4. Sediment production in the events grouped by hierarchical cluster analysis for the watershed with regeneration Caatinga of the Iguatu Experimental Basin.

The watershed TC, similarly to the RC, also presented three different groups of similar events. The group 1 represented $52.17 \%$ of the events with SP (Table 5), which were differentiated by presenting greater rainfall depths, I30 and erosivity compared with group 2, which had 5 rainfall events and, in turn, had the greatest 5-day accumulated precipitation (Table 5). 
Table 5. Characteristics of the events grouped by hierachical cluster analysis for the watershed with Thinned Caatinga of the Iguatu Experimental Basin.

\begin{tabular}{|c|c|c|c|c|}
\hline \multicolumn{5}{|c|}{ Thinned Caatinga } \\
\hline \multirow{6}{*}{$\begin{array}{l}\text { Precipitation } \\
\text { (mm) }\end{array}$} & Variables & Group 1 & Group 2 & Group 3 \\
\hline & Number of events & 12 & 5 & 1 \\
\hline & Average $+\mathrm{SD}$ & $50.52 \pm 13.00$ & $20.58 \pm 51.00$ & 162.00 \\
\hline & Median & 56.13 & 23.00 & $*$ \\
\hline & Maximum & 64.00 & 24.38 & $*$ \\
\hline & Minimum & 31.88 & 12.13 & $*$ \\
\hline \multirow{5}{*}{$\begin{array}{l}\text { Accumulated } \\
\text { PPT in last } \\
5 \text { days }(\mathrm{mm})\end{array}$} & Number of events & 12 & 5 & 1 \\
\hline & Average + SD & $68.20 \pm 51.70$ & $115.23 \pm 36.60$ & $0.00 *$ \\
\hline & Median & 63.75 & 115.38 & $*$ \\
\hline & Maximum & 140.00 & 169.75 & $*$ \\
\hline & Minimum & 0.00 & 76.38 & $*$ \\
\hline \multirow{5}{*}{$\mathrm{I} 30\left(\mathrm{~mm} \mathrm{~h}^{-1}\right)$} & Number of events & 12 & 5 & 1 \\
\hline & Average + SD & $50.70 \pm 9.60$ & $23.24 \pm 6.80$ & $71.23^{*}$ \\
\hline & Median & 54.70 & 26.29 & $*$ \\
\hline & Maximum & 67.84 & 27.98 & $*$ \\
\hline & Minimum & 36.46 & 12.72 & $*$ \\
\hline \multirow{5}{*}{$\begin{array}{c}\text { Erosivity } \\
\left(\mathrm{MJ} \mathrm{mm} \mathrm{ha}{ }^{-1} \mathrm{~h}^{-1}\right)\end{array}$} & Number of events & 12 & 5 & 1 \\
\hline & Average $+\mathrm{SD}$ & $535.39 \pm 277.00$ & $109.57 \pm 47.40$ & $2869.00 *$ \\
\hline & Median & 603.98 & 109.97 & $*$ \\
\hline & Maximum & 884.24 & 165.92 & $*$ \\
\hline & Minimum & 129.31 & 49.01 & $*$ \\
\hline
\end{tabular}

*Event comprises a single evento of equal average, maximum and minimum.

The group 3 consisted of a single precipitation event of extreme rainfall depth $(162.00 \mathrm{~mm})$ and great erosivity (2869.00 MJ mm ha ${ }^{-1} \mathrm{~h}^{-1}$ ) (Table 5). Boix-Fayos et al. (2006) reported high correlation between extreme precipitation events and SP, which caused this single event to represent a group.

The SP of the group 2 is related to its largest preceding accumulated precipitation values (Table 5). Fang et al. (2012) studied characteristics of 152 rainfall events and their relationship with the runoff and SP in Three Gorges, China, and found events divided into three groups by the K-means clustering method. According to these authors, one of the groups presented smaller rainfall depths, however, the frequency of the precipitation events was not enough to generating runoff and produce sediments.

The groups of the watershed TC (Figure 5) showed greater SP in the group 1, which presented greater I30 compared with group 2. The herbaceous vegetation was not efficient enough to prevent the SP due to the great rainfall intensities. According to Rodrigues et al. (2013), herbaceous vegetation promotes a kinetic energy dissipation effect of raindrops, reducing the disaggregation process of soil particles and soil erosion losses, however, extreme events, like the ones of group 2, may result in different effects.

The results of the watershed DC also formed three different groups of events with SP. The group 1 consisted of events with the lowest rainfall depths, I30 and erosivity (Table 6), however presenting similar averages of 5-day accumulated precipitation to the group 2. The group 3 had greater precipitation depth $(162 \mathrm{~mm})$ and erosivity $\left(2869 \mathrm{MJ} \mathrm{mm} \mathrm{ha}^{-1} \mathrm{~h}^{-1}\right)$ showing a possible direct relationship between these two variables (Table 3). Zhou et al. (2016) assessed the relationship between precipitation and hydro-sedimentological processes and found the I30 as the determining factor for the formation of similar groups of events with SP. 


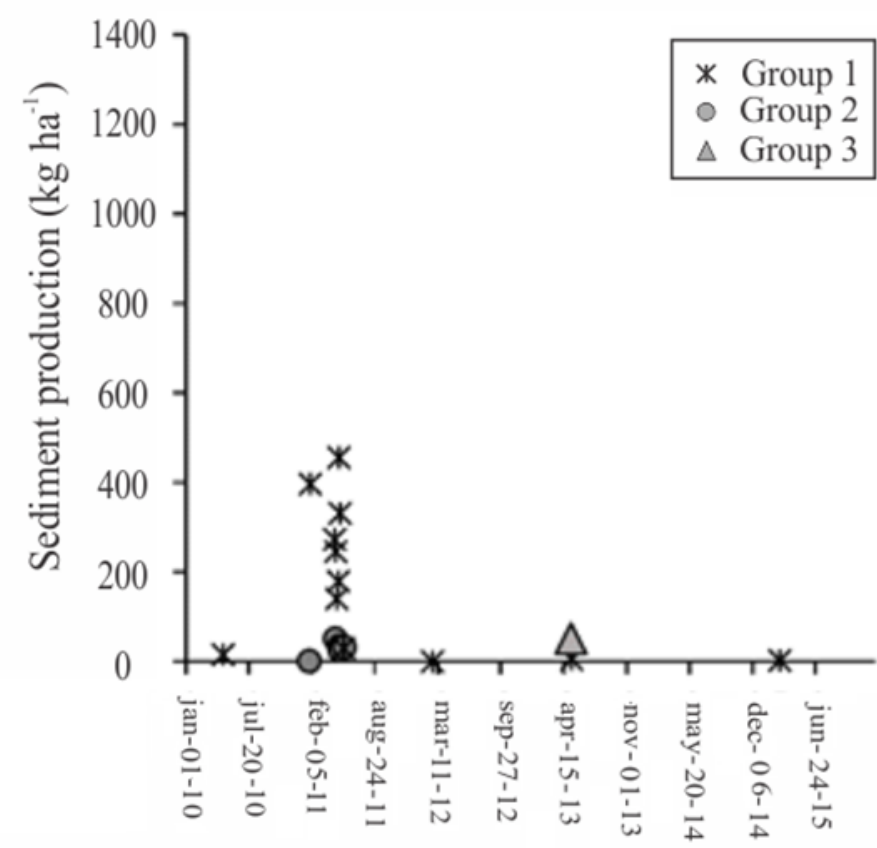

Figure 5. Sediment production in the events grouped by hierarchical cluser analysis for the watershed with thinned Caatinga of the Iguatu Experimental Basin.

Table 6. Chaaracteristics of the events grouped by hierarchical cluster analysis for the watershed with deforested Caatinga (followed by burning and pasture) of the Iguatu Experimental Basin.

\begin{tabular}{|c|c|c|c|c|}
\hline \multicolumn{5}{|c|}{ Deforested Caatinga (followed by burning and pasture) } \\
\hline \multirow{6}{*}{$\begin{array}{l}\text { Precipitation } \\
\quad(\mathrm{mm})\end{array}$} & Variable & Group 1 & Group 2 & Group 3 \\
\hline & Number of events & 17 & 25 & 1 \\
\hline & Average + SD & $23.23 \pm 8.00$ & $51.98 \pm 13.60$ & $162.00 *$ \\
\hline & Median & 20.20 & 55.10 & $*$ \\
\hline & Maximum & 73.90 & 73.90 & $*$ \\
\hline & Minimum & 7.60 & 15.60 & $*$ \\
\hline \multirow{5}{*}{$\begin{array}{l}\text { Accumulated } \\
\text { PPT in last } \\
5 \text { days }(\mathrm{mm})\end{array}$} & Number of events & 17 & 25 & 1 \\
\hline & Average + SD & $92.69 \pm 33.70$ & $101.38 \pm 46.10$ & $0.00 *$ \\
\hline & Median & 78.85 & 100.10 & $*$ \\
\hline & Maximum & 173.30 & 202.00 & $*$ \\
\hline & Minimum & 16.95 & 43.25 & $*$ \\
\hline \multirow{5}{*}{$\mathrm{I} 30\left(\mathrm{~mm} \mathrm{~h}^{-1}\right)$} & Number of events & 17 & 25 & 1 \\
\hline & Average + SD & $24.46 \pm 12.10$ & $56.55 \pm 46.10$ & $71.23^{*}$ \\
\hline & Median & 20.35 & 56.00 & $*$ \\
\hline & Maximum & 84.38 & 97.50 & $*$ \\
\hline & Minimum & 11.87 & 29.68 & $*$ \\
\hline \multirow{5}{*}{$\begin{array}{c}\text { Erosivity } \\
\left(\mathrm{MJ} \mathrm{mm} \mathrm{ha}^{-1} \mathrm{~h}^{-1}\right)\end{array}$} & Number of events & 17 & 25 & 1 \\
\hline & Average + SD & $105.77 \pm 137.60$ & $561.48 \pm 346.60$ & $2869.00 *$ \\
\hline & Median & 78.90 & 495.21 & $*$ \\
\hline & Maximum & 308.40 & 1781.77 & $*$ \\
\hline & Minimum & 9.00 & 3.55 & $*$ \\
\hline
\end{tabular}

*Event comprises a single evento f equal average, maximum and minimum. 
Different than the other two managements, the events that produced more sediments in the DC were grouped in group 2 (Figure 6), since a single event of this group produced $1298.7 \mathrm{~kg} \mathrm{ha}^{-1}$. This event occurred shortly after the burning of the vegetation in the area, leaving the soil exposed. This fact, combined with the kinetic energy of the rain drops (I30 $\left.=58.93 \mathrm{~mm} \mathrm{~h}^{-1}\right)$ caused detachment of the particles (ALBUQUERQUE et al., 2005). Fang et al. (2013) found magnitude of SP determined by few events with high capacity of particle transport.

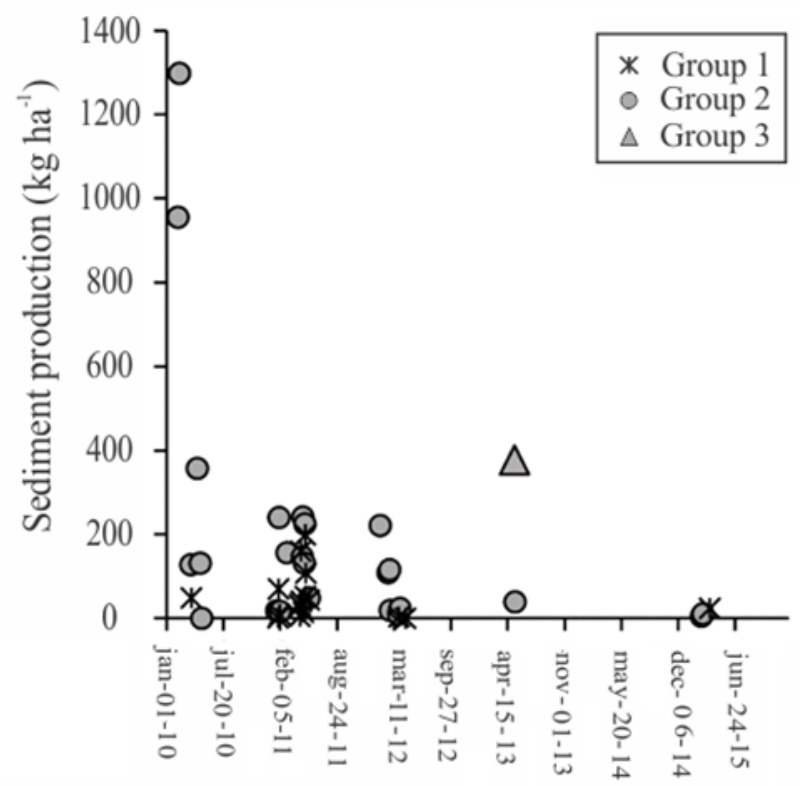

Figure 6. Sediment production in the events grouped by hierarchical cluster analysis for the watershed with deforested Caatinga (followed by burning and pasture) of the Iguatu Experimental Basin.

\section{CONCLUSIONS}

The watershed with thinned Caatinga (TC) reduced the sediment production (SP) by $53.5 \%$, while the watershed with deforested Caatinga (followed by burning and pasture) (DC) increased the SP, compared with the watershed with regenerating Caatinga for 35 years (RC), thus denoting the importance of vegetation for sediment retention. The greatest sediment production occurred in $\mathrm{DC}$, in the first two events after deforestation and burning, when the soil was fully exposed. According to the rainfall characteristics, the sediment production in the three land uses was high correlated with the I30, denoting the greater dependence of the erosion process on the precipitation intensity.

\section{ACKNOWLEDGEMENTS}

The authors thank the National Council for Scientific and Technological Development (CNPq), and the Ceará State Foundation of Support for Scientific and Technological Development (FUNCAP) for financial support, by granting scientific research scholarships to the authors.

\section{REFERENCES}

ALBUQUERQUE, A. W. et al. Determinação de fatores da equação universal de perda de solo em Sumé, PB. Revista Brasileira de Engenharia Agrícola e Ambiental, Campina Grande, v. 9, n. 2, p. 153-160, 2005.

ARAÚJO FILHO, J. A. Manipulação da vegetação lenhosa da caatinga para fins pastoris. 1. ed. Sobral: EMBRAPA-CNPC, 1992. 18 p. (Circular Técnica, 11).

ARAÚJO NETO, J. R. Efeito de diferentes manejos sobre o escoamento superficial em microbacias experimentais no semiárido tropical. 2012. 128 f. Dissertação (Mestrado em Engenharia Agrícola: Área de Concentração em Manejo de Bacias Hidrográficas) - Universidade Federal do Ceará, Fortaleza, 2012.

BOIX-FAYOS, C. et al. Measuring soil erosion by field plots: understanding the sources of variation. Earth-Sciences Reviews, Amsterdam, v. 78, n. 3, p. 267-285. 2006.

CAMPO, J. et al. Occurrence of soil erosion after repeated experimental fires in a Mediterranean environment. Geomorphology, Amsterdam, v. 82, n. 3, p. 367-387, 2006

CHAMIZO, S. et al. Runoff at contrasting scales in a 
semiarid ecosystem: a complex balance between biological soil crust features and rainfall characteristics. Journal of Hydrology, Amsterdam, v. 452, n. 1-4, p. 130-138 2012.

DERECZYNSKI, C. P.; OLIVEIRA, J. S.; MACHADO, C. O. Climatologia da precipitação no município do Rio de Janeiro. Revista Brasileira de Metereologia, São José dos Campos, v. 24, n. 1, p. 24-38, 2009.

FANG, N. F. et al. The characteristics of extreme erosion events in a small mountainous watershed. PloS one, San Francisco, v. 8, n. 10, p. 1-10, 2013.

FANG, N. F. et al. The effects of rainfall regimes and land use changes on runoff and soil loss in a small mountainous watershed. Catena, Amsterdam, v. 99, n. 1. p. 1-8, 2012.

FOOD AND AGRICULTURE ORGANIZATION OF THE UNITED NATIONS - FAO. La erosion del suelo por El água: algunas medidas para combatirla en las tierras de cultivo. Roma, 1967, 207 p.

FOSTER, G. R. et al. Conservation of the Universal Soil Loss Equation the SI metric units. Journal of Soil and Water Conservation, Ankeny, v. 36, n. 6, p. $355-359,1981$.

LIMA, C. A. et al. Characteristics of rainfall and erosion under natural conditions of land use in semi-arid regions. Revista Brasileira de Engenharia Agrícola e Ambiental, Campina Grande, v. 17, n. 11, p. 1222-1229, 2013.

LIU, Y. et al. Hydrological responses and soil erosion potential of abandoned cropland in the Loess Plateau, China. Geomorphology, Amsterdam, v. 138, n. 1, p. 404-414, 2012.

OLIVEIRA, J. R. et al. Erosão hídrica em um argissolo vermelho-amarelo, sob diferentes padrões de chuva simulada. Revista Brasileira de Engenharia agrícola e Ambiental, Campina Grande, v. 14, n. 2, p. 140-147, 2010.

ONDA, Y.; DIETRICH, W. E.; BOOKER, F. Evolution of overland flow after a severe forest fire, Point Reyes, California. Catena, Amsterdam, v. 72, n. 1-4, p. 13-20, 2008.

PIVELI, R. P.. KATO, M. T. Qualidade das águas e poluição: aspectos físico-químicos. 1. ed. São Paulo, SP: ABES, 2005. 285 p.

RODRIGUES, J. O. et al. Sediment loss in semiarid small watershed due to the land use. Revista Ciência Agronômica, Fortaleza, v. 44, n. 3, p. 488-498,
2013.

SANTOS, H. G. et al. Sistema Brasileiro de Classificação de Solos. 3. ed. Brasília, DF: EMBRAPA SOLOS 2013. 353 p.

SANTOS, J. C. N. et al. Determinação do fator de cobertura e dos coeficientes da MUSLE em microbacias no semiárido brasileiro. Revista Brasileira de Engenharia Agrícola e Ambiental, Campina Grande, v. 18, n. 11, p. 1157-1164, 2014.

SANTOS, J. C. N. Mensuração da erosão do solo no semiárido em diferentes usos de terras e escalas espaciais. 2012. 102 f. Dissertação (Mestrado em Engenharia Agrícola: Área de Concentração em Manejo de Bacias Hidrográficas) Universidade Federal do Ceará, Fortaleza, 2012

SANTOS, J. C. N. et al. . Effect of dry spells and soil cracking on runoff generation in a semiarid micro watershed under land use change. Journal of Hydrology, Amsterdam, v. 551, n. 1-4, p. 1-10, 2016.

SUN, L.; NI, J.; BROTHWICK, A. G. L. Rapid assessment of sustainability in Mainland China. Journal of Environmental Management, Amsterdam, v. 91, n. 4, p. 1021-1031, 2010.

THOMAZ, E. L. The influence of traditional steep land agricultural practices on runoff an soil loss. Agricultural, Ecosystem and environment, Amsterdam, v. 130, n. 2, p. 23-30, 2009.

WESTER, T.; WASKLEWICZ, T.; STALEY, D. Functional and structural connectivity within a recently burned drainage basin. Geomorphology, Amsterdam, v. 206, n. 2, p. 362-373, 2014.

WISCHMEIER, W. H; SMITH, D. D. Predicting rainfall erosion losses: A guide to conservation planning. Washington: USDA, 1978. 58 p. (Agricultural Handbook, 537).

ZHOU, J. et al. Effects of precipitation and restoration vegetation on soil erosion in a semi-arid environment in the Loess Plateau, China. CATENA, Amsterdam, v. 137, n. 1-4, p. 1-11, 2016. 